\title{
Effective Removal of Nitrates from the Drinking Water by Chemical and Electrochemical Methods
}

\author{
S. Ramalingam ${ }^{1,2, *}$ and A. Subramania ${ }^{2,3, *}$
}

\begin{abstract}
In the present study, the effective removal of nitrates from the water was investigated using the nano alumina adsorbent and then the electrochemical method for the removal of nitrates using Pt anode and brass cathode were studied. Nano alumina has been used as an adsorbent to remove nitrates from aqueous solutions. The effects of contact time, adsorbent dosage and initial nitrate concentrations on the adsorption process have been investigated. The effects of $\mathrm{pH}$ and temperature on adsorption have been studied in order to optimize the range. Furthermore, the electrochemical method for the removal of nitrates using a Pt anode and a brass cathode has been observed to produce excellent results. The nitrate removal efficiency increases with electrolysis time in the current density range from 1 to $2 \mathrm{~A} \mathrm{dm}^{-2}$. Maximum nitrate $\left(\mathrm{NO}_{3}{ }^{-}\right)$ ions removal was achieved for nitrate $\left(\mathrm{NO}_{3}^{-}\right)$ions concentrations of $200 \mathrm{mg} / \mathrm{L}$ after 90 minutes of electrolysis at a current density of $2 \mathrm{~A} \mathrm{dm}^{-2}$. Direct nitrate reduction is possible at all nitrate concentrations and begins at a potential below $300 \mathrm{mV}$ vs. saturated calomel electrode (SCE) in the cyclic voltammetry (CV) studies. From the CV and differential pulse stripping voltammetry (DPSV) studies, we have known that electrocatalytic reduction has a direct relationship between current and electrode potential. In CV, the electrode potential was found to be below $300 \mathrm{mV}$ and DPSV showed that an electro-catalytic reduction occurred at a potential of $300 \mathrm{mV}$. From these studies, we infer that $\mathrm{NO}_{3}{ }^{-}$ions are adsorbed on platinum electrode surfaces and desorbed from the surface. The adsorbed $\mathrm{NO}_{3}{ }^{-}$ion is converted into $\mathrm{NO}_{2}{ }^{-}$(nitrite) ions on the electrode surface (this is the rate-determining step) and the $\mathrm{NO}_{2}{ }^{-}$ion is converted into $\mathrm{NO}, \mathrm{N}_{2} \mathrm{O}$, and finally into $\mathrm{N}_{2}$ gas.
\end{abstract}

Keywords: Nitrate removal; Water; Chemical and electrochemical methods; Adsorption; Nanoalumina adsorbent; Electrolysis; Electrocatalytic reduction.

Received: 21 December 2020; Accepted date: 14 April 2021.

Article type: Research article.

\section{Introduction}

Many water supply authorities face problems associated with the high concentration of Nitrates $\left(\mathrm{NO}_{3}^{-}\right)$in groundwater. ${ }^{[1-3]}$ This should be controlled in drinking water principally because excess levels can cause methemoglobinemia. Methemoglobinemia is the most important health problem

1 Department of Chemistry, School of Advanced Sciences, Kalasalingam Academy of Research and Education (Deemed to be University), Krishnankoil-626 126, India.

${ }^{2}$ Department of Industrial Chemistry, School of Chemical Sciences, Alagappa University, Karaikudi 630003 . India.

${ }^{3}$ Centre for Nanoscience and Technology, Pondicherry University Puducherry 605 014, India.

*E-mail: rama.s.lingam@gmail.com (S. Ramalingam),

a.subramania@gmail.com (A. Subramania) associated with nitrate in drinking water. ${ }^{[4]}$ The blood contains an iron-based compound called hemoglobin, which carries oxygen. When nitrate is present, hemoglobin can be converted to methemoglobin, which cannot carry oxygen.

About $90 \%$ of the world's drinking water supplies are groundwater sources. Due to modern agricultural practices, natural background levels, and other sources such as on-site wastewater disposal systems, the nitrate concentration in groundwater is increasing day by day. It is well known that the health effect is caused by the nitrates $\left(\mathrm{NO}_{3}{ }^{-}\right)$present in drinking water sources greater than $50 \mathrm{mg} / \mathrm{L}$. Nitrate in drinking water is measured either in terms of the amount of nitrogen present (or) in terms of both nitrogen and oxygen. The WHO standard for nitrate in drinking water is $50 \mathrm{mg} / \mathrm{L}$ as nitrate- $\mathrm{NO}_{3}$ or 11 milligrams per liter of nitrate-N..$^{[5-7]}$ So, if the Nitrate level exceeds the permissible limit, the potable water 
must be treated.

A wide range of physicochemical processes, such as ion exchange, reverse osmosis, electrodialysis, chemical denitrification and biological denitrification is currently being developed to remove nitrate from drinking water, primarily for large-scale water treatment plants. ${ }^{[8-21]}$ Ion exchange, reverse osmosis and electro-dialysis are cost-intensive as well as labor-intensive. Biological denitrification reduces the species of nitrate to gaseous nitrogen. Though it is an efficient technology for removing nitrates, biological denitrification is slow, difficult to monitor and produces organic residues, bacteria are sensitive to heavy metal ions and changes in the composition of the influent stream. ${ }^{[17,18]}$ So far, limited research works have been reported on the purification of water by activated carbon, activated alumina adsorbents, and conducting polymers. ${ }^{[22-30]}$ A simple technique of removal of nitrate is urgently required to curb the nitrate menace. With these in mind, the following objectives for the present work are perceived.

The objective of this present research work is to examine the simple chemical and electrochemical methods for the effective removal of nitrates from potable water. Two methods have been investigated in this study. First, the removal of nitrate was studied with novel adsorbent nano-alumina by the chemical process. Batch studies were performed with various control factors such as contact time effect, initial concentration, alumina dose, $\mathrm{pH}$, temperature, etc. These batch studies reported the adsorption rate, optimum nitrate removal. The electrochemical approach receives more attention due to its advantages such as environmental compatibility, versatility, safety, amenability, and cost-effectiveness, etc. In our present study, we have used brass as an effective cathode material and solid platinum as anode for the electrolysis process of nitrate removal from aqueous solutions. Previously, there are few reports on electrochemical nitrate reduction was carried out using the various electrodes such as metals, binary metals and alloys, metal complexes and synthetic diamonds. Of these, binary metal electrodes, such as $\mathrm{Cu} / \mathrm{Pt}$ showed higher catalytic activity was reported. ${ }^{[31-39]}$

\section{Experimental section}

\subsection{Materials}

Nano-alumina $\left(\mathrm{Al}_{2} \mathrm{O}_{3}\right)$ powder with the grain size of $50 \mathrm{~nm}$ was purchased from Sigma-Aldrich and other chemicals such as sodium nitrate $\left(\mathrm{NaNO}_{3}\right)$, brucine sulphate, sulphanilic acid and sulphuric acid are purchased from Merck. All reagents were used in this study are of analytical grade. De-ionized water is used for the preparation of nitrate stock solution. By proper dilution of stock solution with de-ionized water, the standards and samples of the specified concentration range have been prepared and used in this study.

\subsection{Experimental Methods}

\subsubsection{Removal of Nitrates $\left(\mathrm{NO}_{3}{ }^{-}\right)$using Nano-alumina $\left(\mathrm{Al}_{2} \mathrm{O}_{3}\right)$ adsorbent}

The removal of nitrate was achieved by adding nano-alumina $\left(\mathrm{Al}_{2} \mathrm{O}_{3}\right)$ powder to the water sample. The nitrates ions are adsorbed on the alumina surface and are separated from the water. The residual concentration of nitrate ions was calorimetrically measured using the brucine test. In this process, the Nitrate ions in the strong sulphuric acid solution react with brucine to form a yellow colour, the absorbance of the samples are measured after setting the blank at $100 \%$ transmittance at a wavelength of $410 \mathrm{~nm}$ using Shimadzu UV -2401 PC UV-Visible spectrophotometer. From the measured absorbance values, the residual concentration and removal efficiency was calculated by using the Beer-Lambert law.

\subsubsection{Estimation of nitrate by Brucine Method}

In a series of $50 \mathrm{ml}$ beakers, $10 \mathrm{ml}$ of standard sodium nitrate solution was taken as a blank, standard and sample solution in each beaker. Then, $1 \mathrm{ml}$ of Brucine - sulphanilic acid solution was added to each beaker.

In the second series of $50 \mathrm{ml}$ beakers, $10 \mathrm{ml}$ sulphuric acid solution was taken and the contents of the first series of $50 \mathrm{ml}$ beakers containing blank, standard and sampled were transferred to each of the second series of $50 \mathrm{ml}$ beakers containing sulphuric acid solution and mixed well, then poured from one beaker to the other $4-6$ times to ensure complete mixing and kept the beakers in the dark for $10 \mathrm{~min}$. As the colour develops, $10 \mathrm{ml}$ of distilled water was added to the respective beakers containing the blank, standard and sample. These solutions were kept in the dark for 20 minutes. Finally, the absorbance of the standards and samples shall be measured with Shimadzu (Model: 2401) UV - Vis spectrophotometer after setting the blank at $100 \%$ transmittance at the wavelength of $410 \mathrm{~nm}$. Residual concentration and removal efficiency were calculated using Beer-Lambert law from the measured absorbance values.

\subsubsection{Adsorption of nitrate on alumina}

$100 \mathrm{ml}$ of standard sodium nitrate $\left(200 \mathrm{mg} / \mathrm{L} \mathrm{NaNO}_{3}\right)$ solution was taken in a conical flask. To this, $3 \mathrm{~g}$ of adsorbent nanoalumina was added and kept for half an hour in the auto-shaker The solution had been allowed to settle for 10 minutes after shaking, and then the solution was filtered with Whatman filter paper. The filtered sample solution was taken for estimation. Batch experiments are conducted on nitrate removal with the variance of initial nitrate concentration and alumina dosage, the effect of contact time, $\mathrm{pH}$, and effects of temperature.

\subsubsection{Electrochemical methods for the removal of nitrates 2.2.4.1 Nitrate removal by a simple electrolysis process} The standard solution of $200 \mathrm{ml}$ of $\mathrm{NaNO}_{3}(200 \mathrm{ppm})$ was used for the electrolysis. The positive terminal of the DC power supply is connected to the $\mathrm{Pt}$ anode and the negative terminal is connected to the brass cathode. The electrolysis was performed with the current density range applied from 1-2 A $\mathrm{dm}^{-2}$ for 90 minutes. 

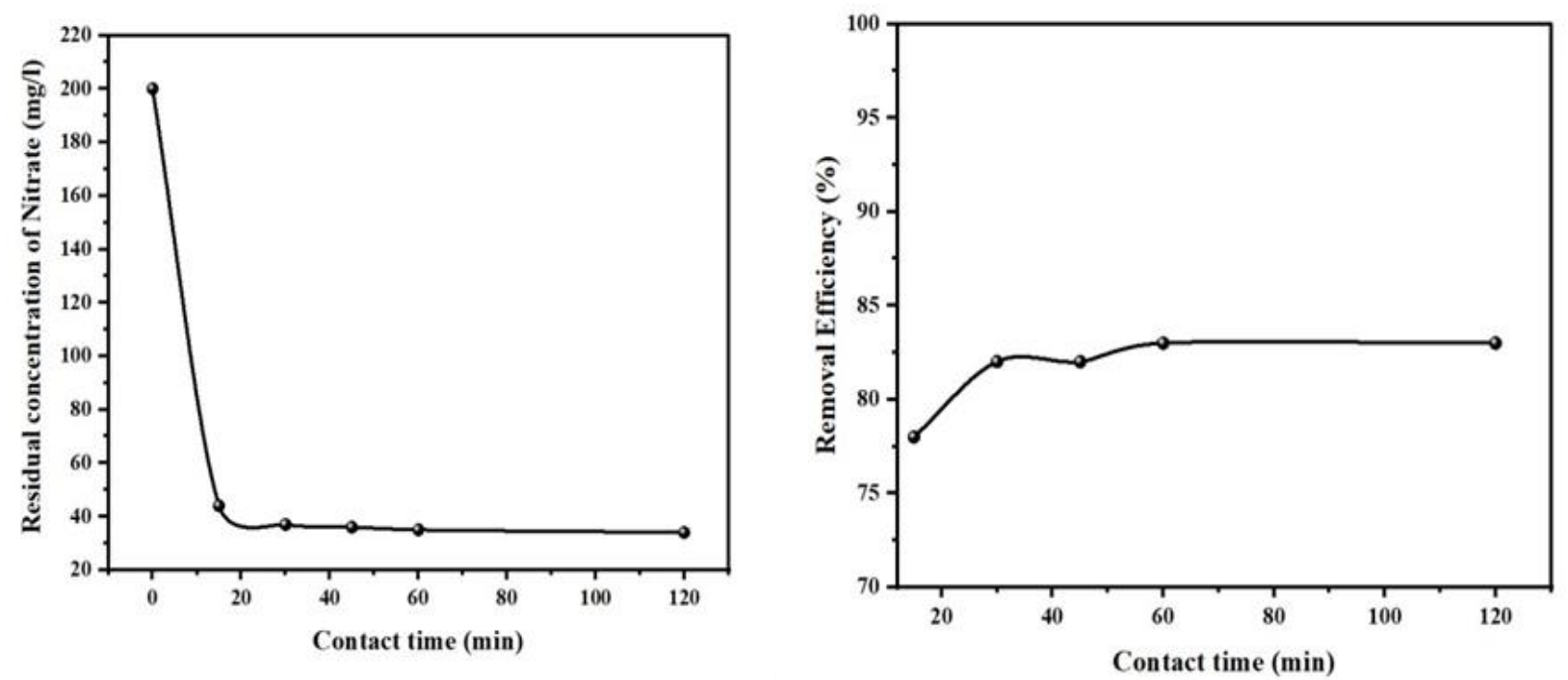

Fig. 1 Effect of contact time on nitrate removal.

\subsubsection{Electrocatalytic reduction of nitrates}

The electrocatalytic reduction of nitrate $\left(\mathrm{NO}_{3}^{-}\right)$ions on the $\mathrm{Pt}$ electrode have been studied with different concentrations of nitrates by cyclic voltammetry (CV) and differential pulse stripping voltammetry (DPSV) techniques. All electrochemical measurements were carried out with an Electrochemical analyzer (EG \& G Princeton Applied Research model 273A Potentiostat/Galvanostat). A cyclic voltammogram $(\mathrm{CV})$ was taken to test $200 \mathrm{mg} / \mathrm{L} \mathrm{NaNO}_{3}$ solution is taken on Pt electrode vs SCE for nitrate $\left(\mathrm{NO}_{3}{ }^{-}\right)$ reduction. The reduction of $\mathrm{NO}_{3}^{-}$ion on $\mathrm{Pt} v \mathrm{vs}$. $\mathrm{SCE}$ with the potential region of -100 to $1300 \mathrm{mV}$ (i.e., -0.1 to $1.3 \mathrm{~V}$ ) was studied by cyclic voltammetry technique.

\section{Results and discussion}

\subsection{Adsorption of nitrate on alumina}

\subsubsection{Effect of contact time}

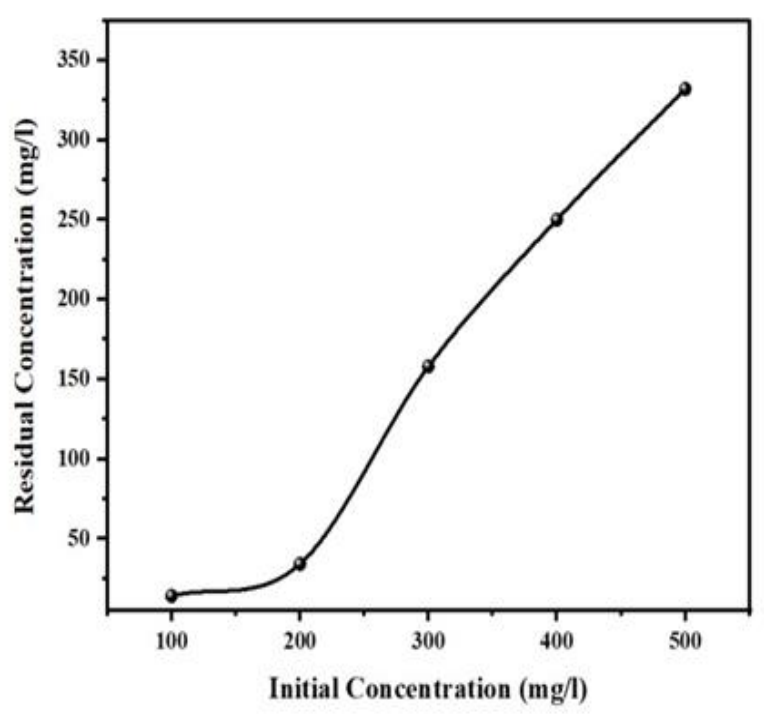

Fig. 1 shows the residual concentration and removal efficiency of nitrate at the contact time of $15,30,45,60$ and 120 minutes. From Fig. 1, it is seen that the process of adsorption reaches its maximum almost $30 \mathrm{~min}$ and reaches equilibrium after 60 min of contact time. It is observed that the initial adsorption rate is high, and this could be because of the availability of more adsorption sites. When the adsorption process continues, the number of vacant adsorption sites available for the adsorption will reduce and the removal rate will decrease after 30 min of contact time. The marginal difference between 30 and $45 \mathrm{~min}$ in removal efficiency is observed. For further studies, the optimum contact time will be taken as 30 minutes.

\subsubsection{Effect of initial concentration}

Fig. 2 shows the residual nitrate concentration and the removal efficiency for the initial concentrations of $100-500 \mathrm{mg} / \mathrm{L}$ at a contact time of $30 \mathrm{~min}$ with a $3 \mathrm{~g}$ dose of alumina.

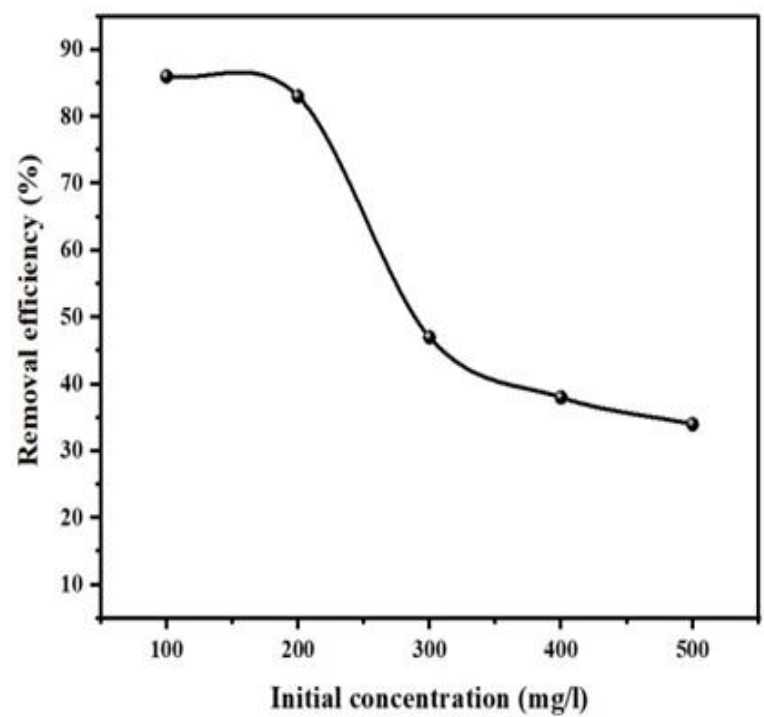

Fig. 2 Effect of initial concentration on nitrate removal. 

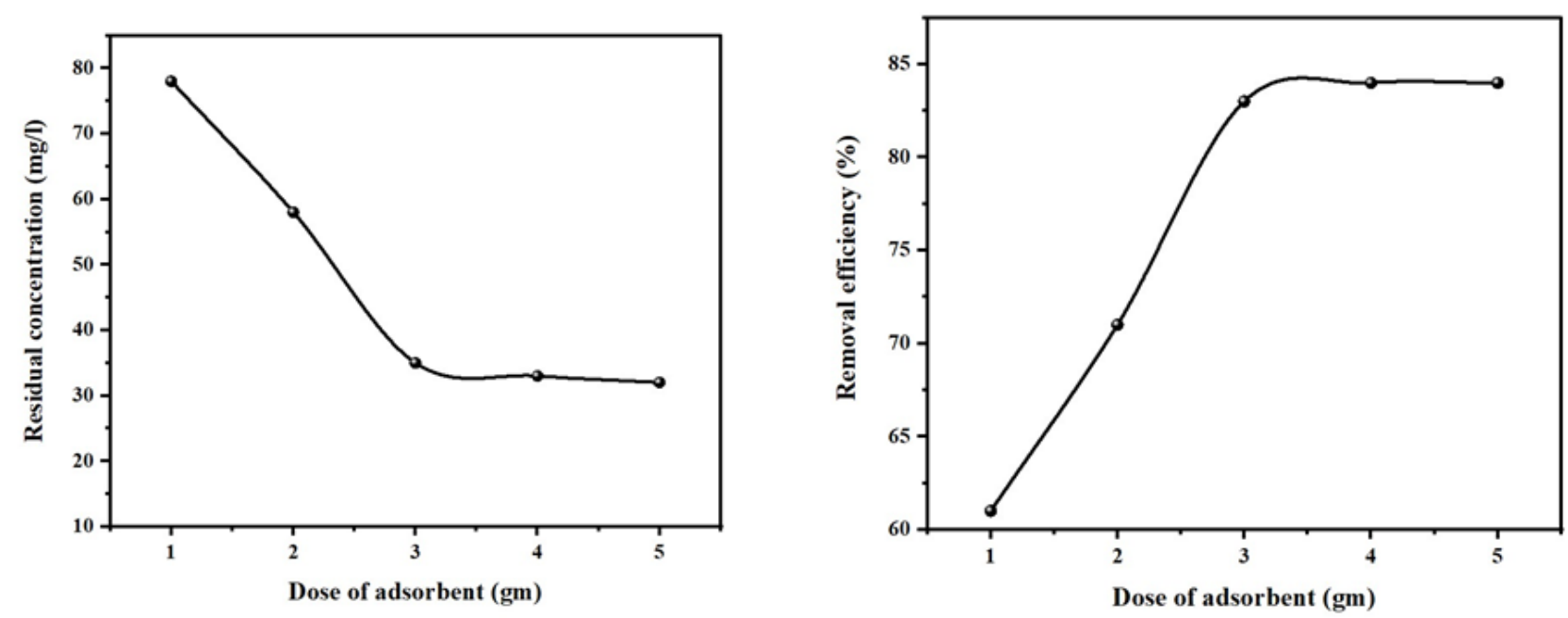

Fig. 3 Effect of alumina dosage on nitrate removal.

From Fig. 2, it is observed that the residual concentration increases, and the efficiency of removal decrease with increasing the initial concentration. The actual amount of nitrate adsorbed is almost the same for the $3 \mathrm{~g}$ of alumina. This could be because the total number of sites available is constant for the dose taken during the process. Thus, the amount of adsorbed nitrate remains constant.

\subsubsection{Effect of alumina dosage on nitrate removal}

Fig. 3 shows the results obtained for the dosage of $1-5 \mathrm{~g}$ of nano-alumina in the initial concentration of $200 \mathrm{mg} / \mathrm{L} \mathrm{NaNO}_{3}$ at the contact time of 30 minutes. By increasing the adsorbent dosage, the residual concentration decreases up to $3 \mathrm{~g}$ and follow abscissa from 3-5 g. Similarly, the efficiency of removal rises to $83 \%$ and remains at $84 \%$. The available difference in concentration of up to $3 \mathrm{~g}$ favours further adsorption. Equilibrium reaches at $3 \mathrm{~g}$ of alumina, and therefore no further removal at the dosage of beyond the $4 \mathrm{~g}$ of alumina.

\subsubsection{Effect of $\mathrm{pH}$ on nitrate removal}

Fig. 4 shows the results obtained on $\mathrm{pH}$. Residual concentration increases with $\mathrm{pH}$, and the removal efficiency often decreases with $\mathrm{pH}$. Increased efficiency at lower $\mathrm{pH}$ could be due to increased activation and positive charges. Generally, acid solutions are used for the activation of any adsorbent. At neutral $\mathrm{pH}$, the efficiency is $83 \%$. At $\mathrm{pH}=4$, the efficiency of removal is $93 \%$.

\subsubsection{Effect of temperature on nitrate removal}

Fig. 5 shows the residual concentration of nitrate and the removal efficiency in the range of temperatures studied 30, 40, 50 and $60^{\circ} \mathrm{C}$. From this results, it is observed that the efficiency of removal is more at normal room temperature, i.e., at a temperature of relatively $30{ }^{\circ} \mathrm{C}$. The nitrates are concentrated at higher temperature.

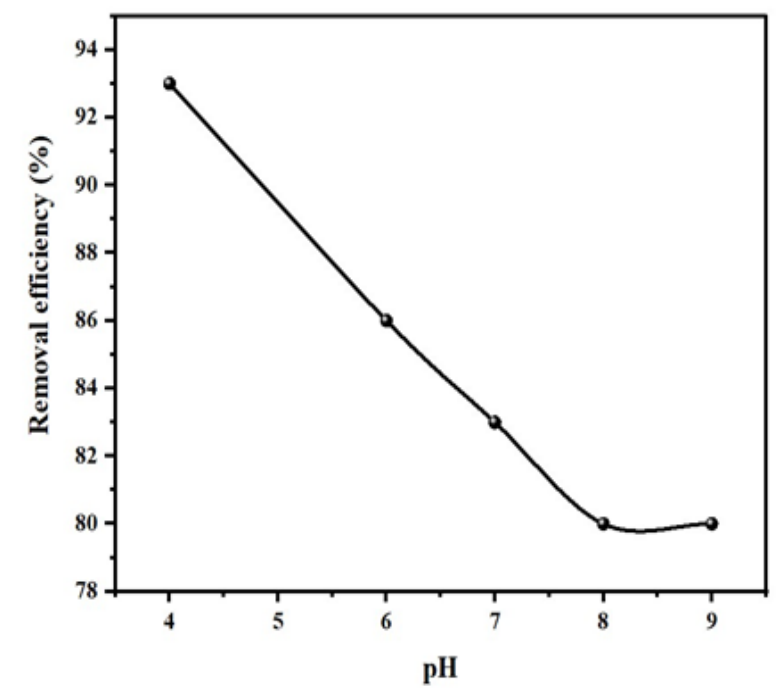

Fig. 4 Effect of $\mathrm{pH}$ on nitrate removal. 

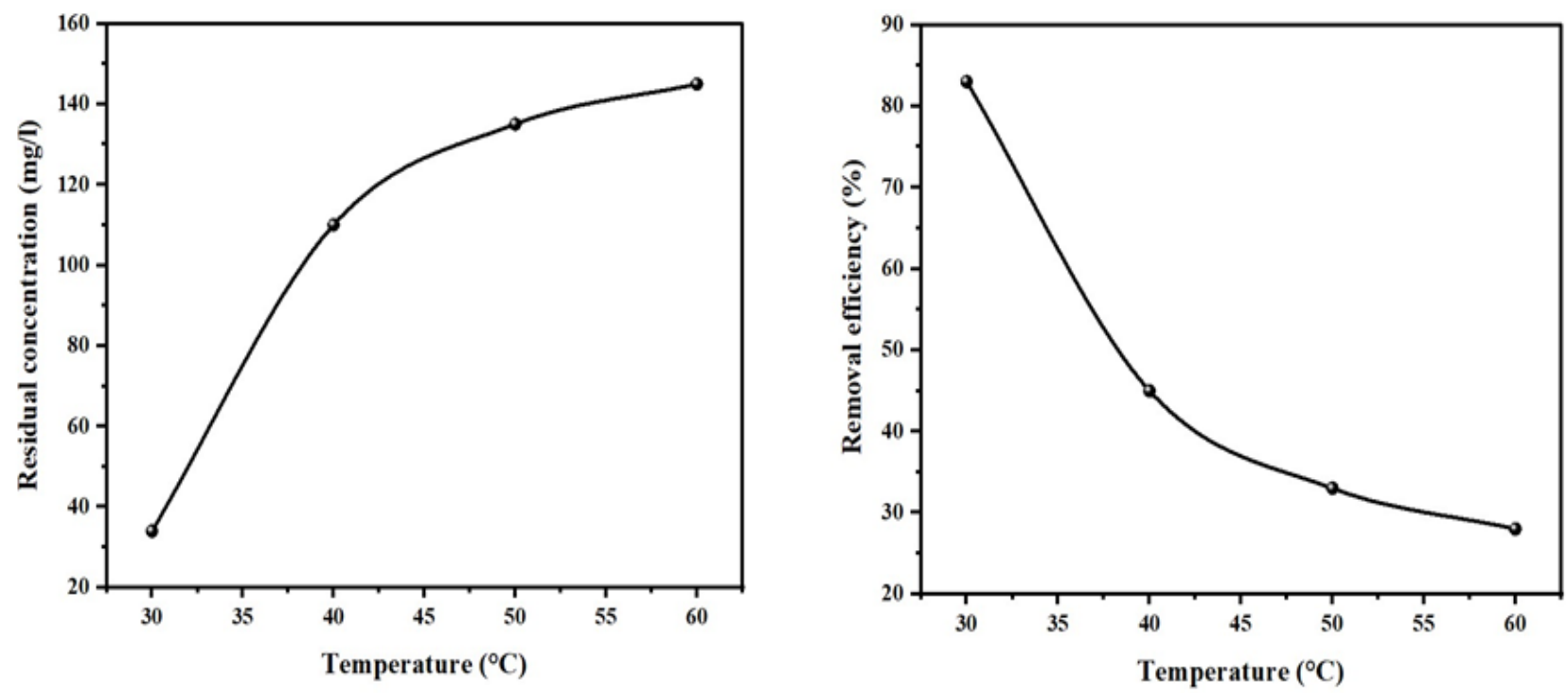

Fig. 5 Effect of temperature on nitrate removal.

\subsubsection{Adsorption isotherm}

Fig. 6 and 7 show that the adsorption isotherm for nitrate removal on the nano-alumina. The process of adsorption obeys Langmuir isotherm since its $\mathrm{R}^{2}$ value is higher than the Freundlich model.

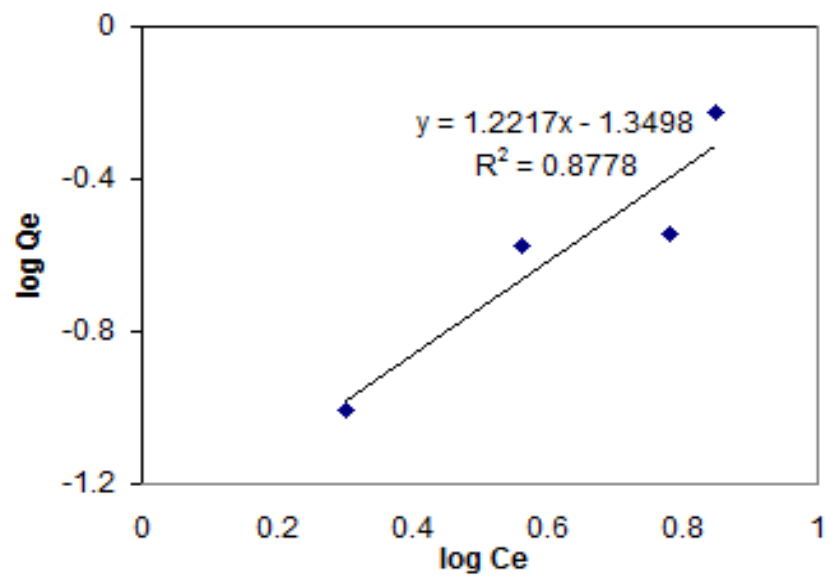

Fig. 6 Freundlich adsorption isotherm.

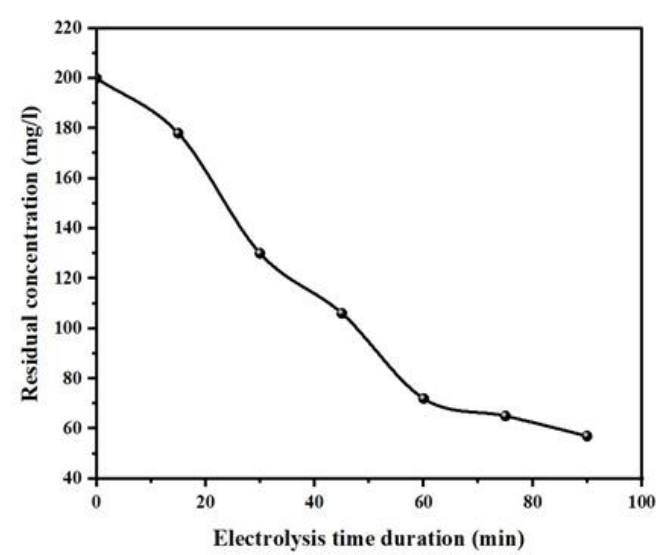

\subsection{Electrochemical method}

\subsubsection{Electrolysis Studies}

\subsubsection{Effect of time}

The results obtained for variation in electrolysis time is shown in Fig. 8, Nitrate removal increases with electrolysis time. By increased electrolysis time, the removal efficiency increases as well.

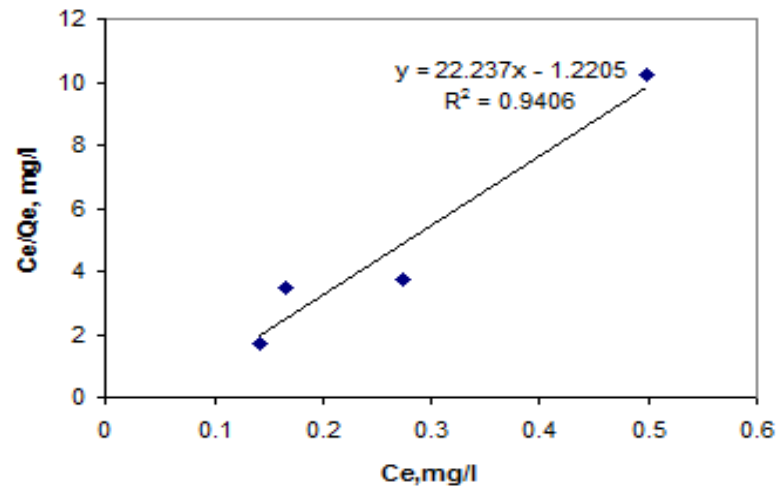

Fig. 7 Langmuir adsorption isotherm.

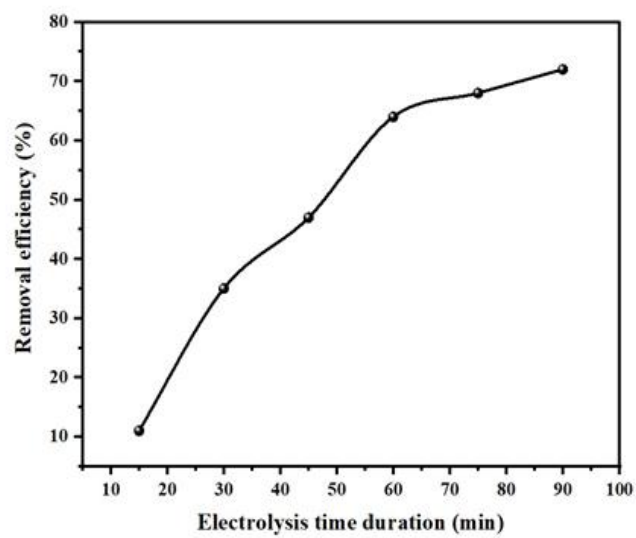

Fig. 8 Effect of electrolysis time on nitrate removal. 

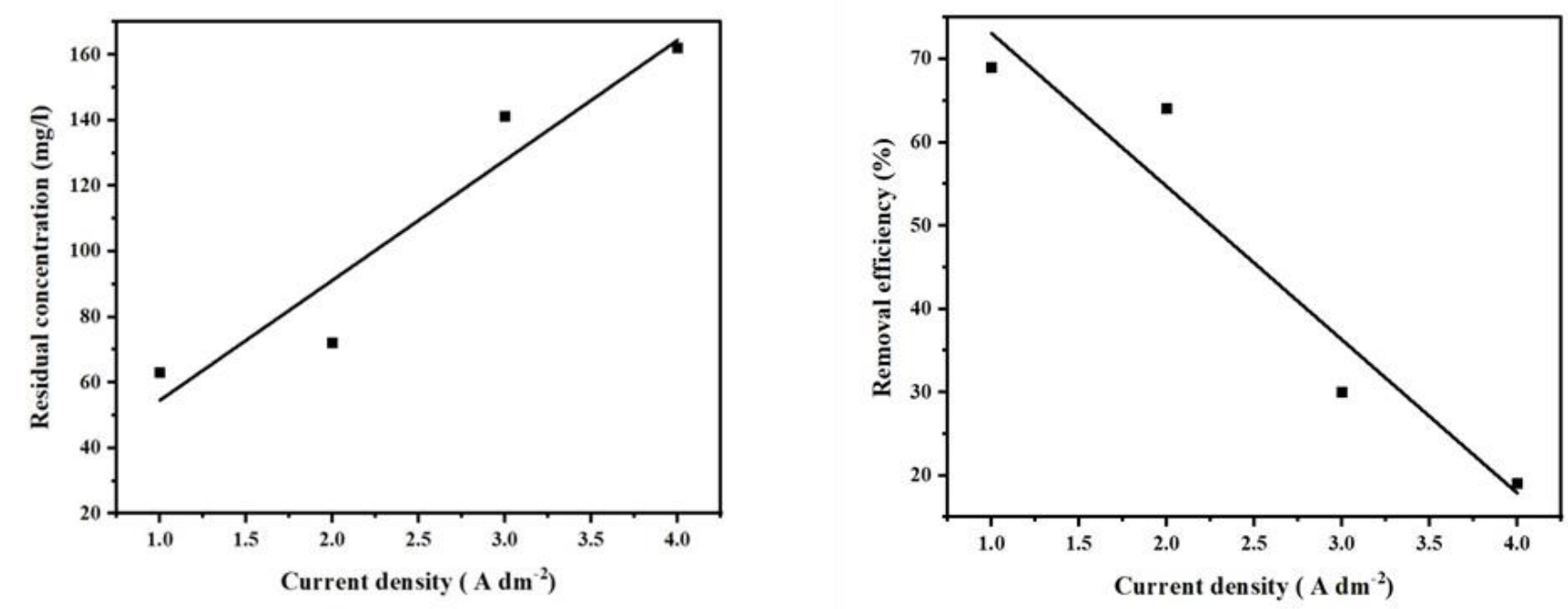

Fig. 9 Effect of current density on nitrate removal.

\subsubsection{Effect of current density}

Fig. 9 shows the results obtained for the current density variation. The removal of nitrate at $1-2 \mathrm{~A} \mathrm{dm}^{-2}$ is good. From these figures, it is observed that it takes more than 60 minutes of electrolysis to bring the concentration of nitrate below 100 $\mathrm{mg} / \mathrm{L}$. This is the permissible limit for drinking purposes.

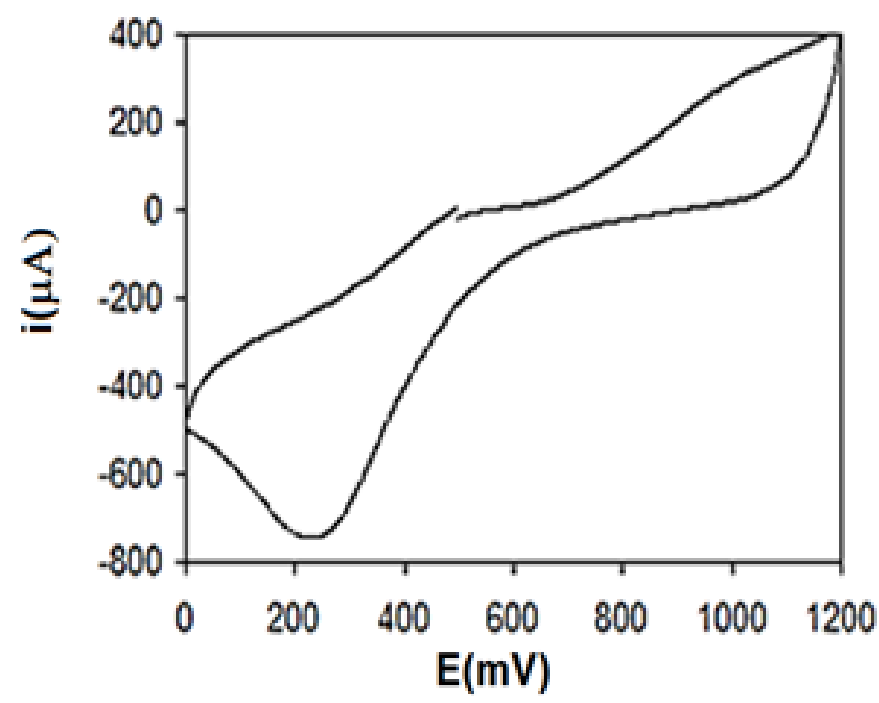

Fig. 10 Cyclic voltammogram for the electrocatalytic reduction of $\mathrm{NO}_{3}{ }^{-}$ion on Pt electrode with $200 \mathrm{mg} / \mathrm{L} \mathrm{NaNO}_{3}$ solution with the scan rate of $50 \mathrm{mV} / \mathrm{s}$.

\subsubsection{Cyclic voltammetry (CV) studies}

The electrocatalytic reduction of $\mathrm{NO}_{3}{ }^{-}$ion on the Pt electrode was studied by Cyclic voltammetry (CV). Fig. 10 shows the electrocatalytic reduction of $\mathrm{NO}_{3}{ }^{-}$ion on Pt electrode with 200 $\mathrm{mg} / \mathrm{L}$ of $\mathrm{NaNO}_{3}$ solution. The reduction of $\mathrm{NO}_{3}{ }^{-}$ion is observed in the potential range below $300 \mathrm{mV}$. The reduction is a direct relationship between the current and the potential. It is also known that the reduction mechanism depends strongly on the nature of electrode, electrode $\mathrm{pH}$, and electrode potential and also the presence of the molecular (or) ionic additives in the solutions. Fig. 11 shows the electrocatalytic reduction of $\mathrm{NO}_{3}{ }^{-}$ion on Pt electrode with $200 \mathrm{mg} / \mathrm{L} \mathrm{NaNO}_{3}$ solution after the 90 minutes of electrolysis at the current density of $2 \mathrm{~A} \mathrm{dm}^{-2}$. The absence of any peak in the Fig. 11 indicates that, there is no nitrate $\left(\mathrm{NO}_{3}^{-}\right)$ions present in the electrolysis sample and it is completely removed during the electrolysis process.

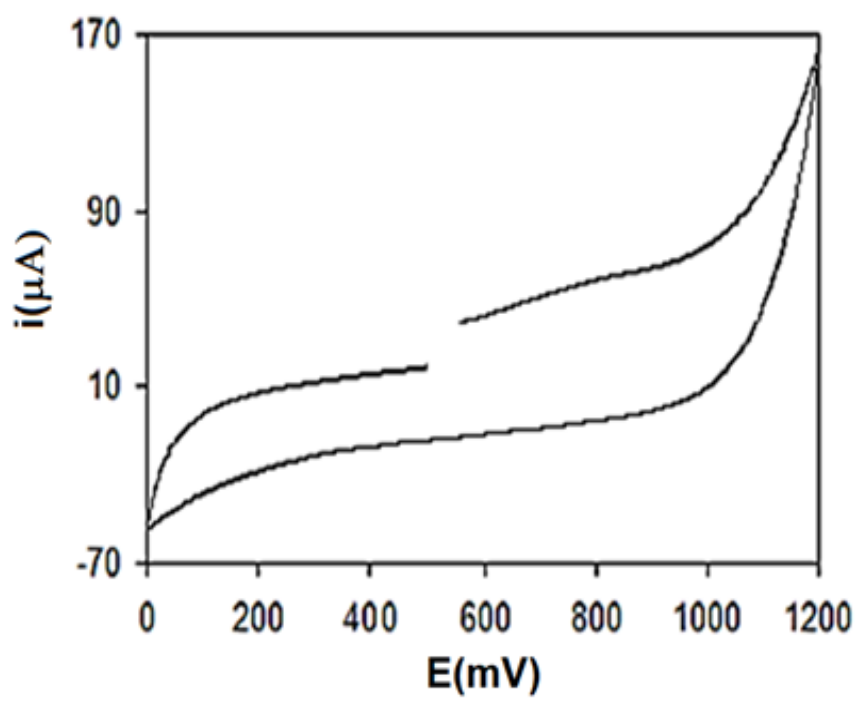

Fig. 11 Cyclic voltammogram obtained for the electrocatalytic reduction of $\mathrm{NO}_{3}{ }^{-}$ion on $\mathrm{Pt}$ electrode with $200 \mathrm{mg} / \mathrm{L} \mathrm{NaNO}_{3}$ solution after $90 \mathrm{~min}$ electrolysis with the scan rate of $50 \mathrm{mV} / \mathrm{s}$.

From the above CV and DPSV Fig. (10 to 14 ), we had known about that the electrocatalytic reduction which has a direct relationship between current and electrode potential. The rate of the reaction depends on the nitrate concentration of the sample solutions. In CV the electrode potential was observed to be below $300 \mathrm{mV}$ and DPSV has shown the electrocatalytic reduction to be at a potential of $300 \mathrm{mV}$. From these studies, we come to the conclusion that $\mathrm{NO}_{3}{ }^{-}$ions are adsorbed on the 
platinum electrode surfaces and desorbed from the surface. The adsorbed $\mathrm{NO}_{3}{ }^{-}$ions are converted into $\mathrm{NO}_{2}{ }^{-}$(Nitrite) ions on the electrode surface (this is the rate- determining step) and the $\mathrm{NO}_{2}{ }^{-}$ions are converted into $\mathrm{NO}, \mathrm{N}_{2} \mathrm{O}$, and finally the $\mathrm{N}_{2}$ gas was produced. The electrochemical reactions involved in the nitrate reduction are given below; ${ }^{[40,41]}$

$$
\begin{gathered}
\mathrm{NO}_{3}^{-} \rightleftharpoons \mathrm{NO}_{3}^{-} \text {ads } \\
\text { (in equilibrium) } \\
\mathrm{NO}_{3 \text { ads }}^{-}+2 \mathrm{H}^{+}+2 \mathrm{e}^{-} \quad \text { Slow } \mathrm{NO}_{2}^{-} \text {ads } \\
\text { (Rate determining Step) } \\
\mathrm{H}_{2} \mathrm{O} \\
\mathrm{NO}_{2}^{-} \text {ads }+2 \mathrm{H}^{+}+2 \mathrm{e}^{-} \longrightarrow \text { Fast } \mathrm{NO}_{\text {ads }}+\mathrm{H}_{2} \mathrm{O} \\
\mathrm{NO}_{\text {ads }}+4 \mathrm{H}^{+}+3 \mathrm{e}^{-} \rightleftharpoons \text { Fast } \mathrm{NH}_{3} \mathrm{OH}^{+} \\
\mathrm{NO}_{\text {ads }}+6 \mathrm{H}^{+}+5 \mathrm{e}^{-} \rightleftharpoons \text { Fast } \mathrm{NH}_{4}^{+}+\mathrm{H}_{2} \mathrm{O} \\
\mathrm{NO}_{\text {ads }}+\mathrm{NO}_{3}^{-}+6 \mathrm{H}^{+}+5 \mathrm{e}^{-} \longrightarrow \mathrm{N}_{2} \mathrm{O}+3 \mathrm{H}_{2} \mathrm{O} \\
\mathrm{NO}_{\text {ads }}+\mathrm{NO}_{2}^{-}+4 \mathrm{H}^{+}+3 \mathrm{e}^{-} \longrightarrow \mathrm{N}_{2} \mathrm{O}+2 \mathrm{H}_{2} \mathrm{O} \\
\mathrm{N}_{2} \mathrm{O}+2 \mathrm{H}^{+}+2 \mathrm{e}^{-} \longrightarrow \mathrm{N}_{2} \uparrow+\mathrm{H}_{2} \mathrm{O}
\end{gathered}
$$

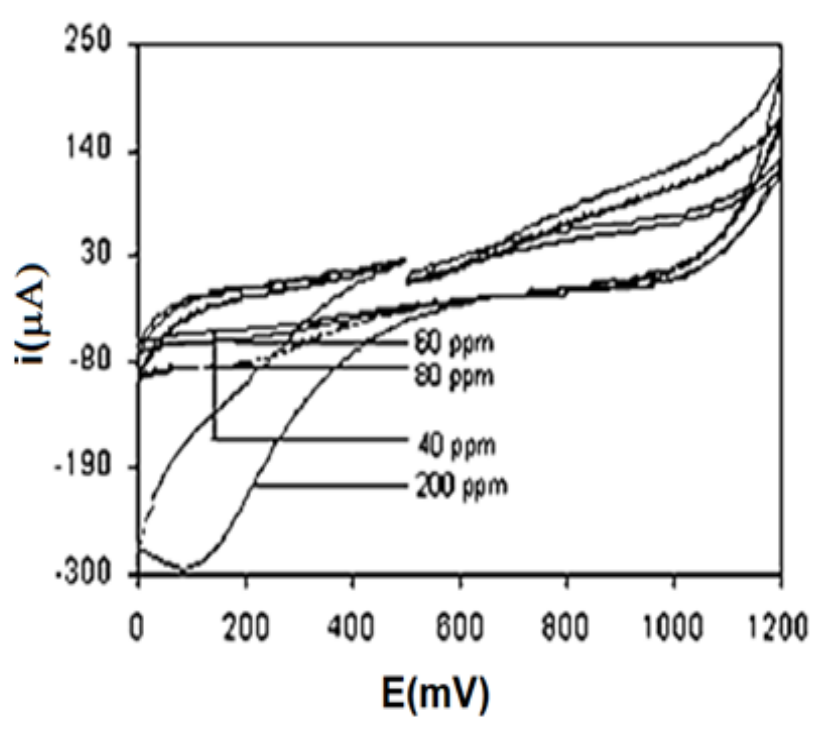

Fig. 12 Cyclic voltammogram obtained for the electrocatalytic reduction on pt electrode with various concentrations of $\mathrm{NaNO}_{3}$ solution at the scan rate of $50 \mathrm{mV} / \mathrm{s}$.

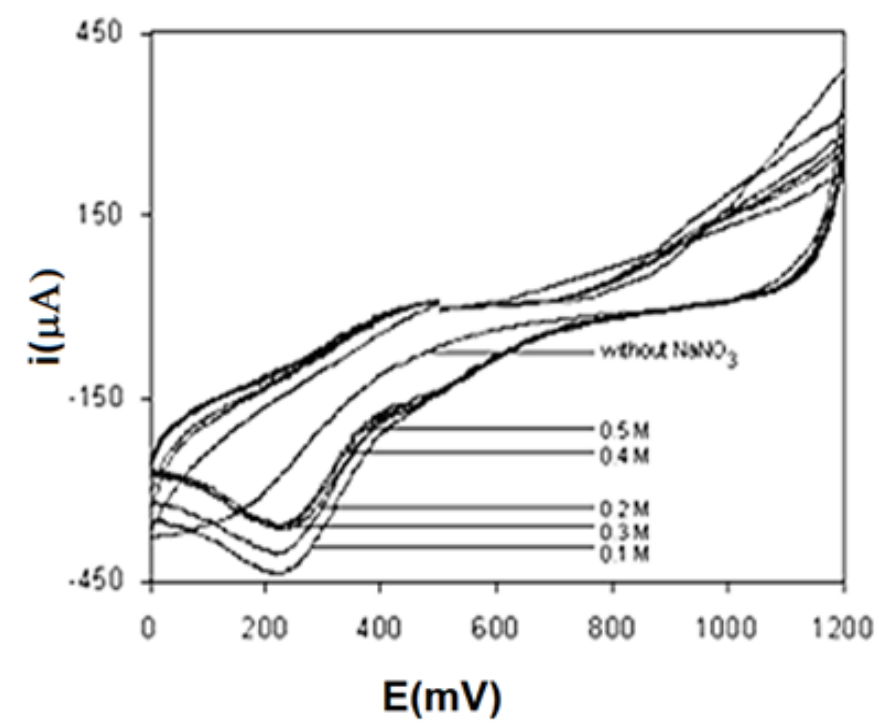

Fig. 13 Cyclic voltammogram obtained for the electrocatalytic reduction of $\mathrm{NO}_{3}^{-}$ion on Pt electrode with $0.5 \mathrm{M} \mathrm{H}_{2} \mathrm{SO}_{4}$ in the potential ranges of below $300 \mathrm{mV}$ at the scan rate of $50 \mathrm{mV} / \mathrm{s}$.

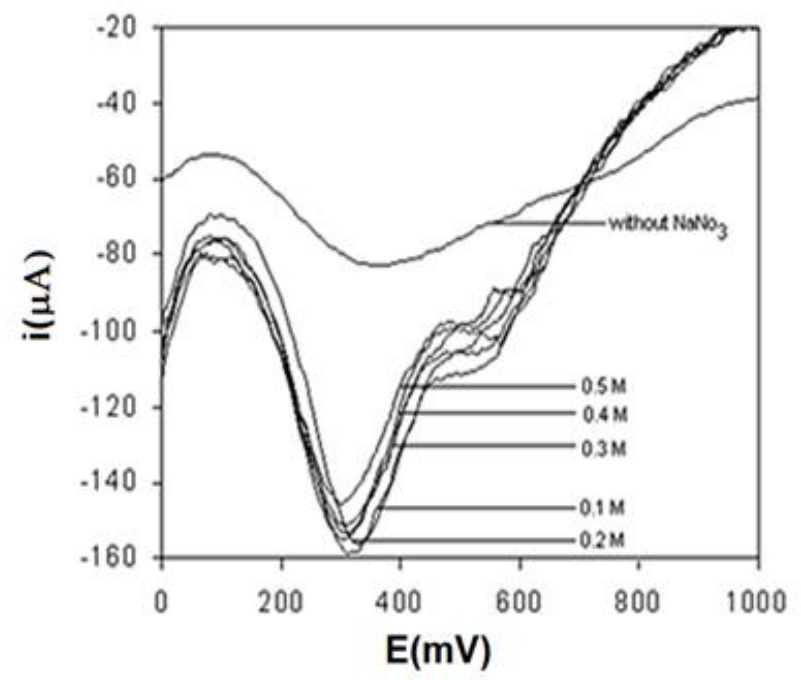

Fig. 14 DPSV electrocatalytic reduction of $\mathrm{NO}_{3}{ }^{-}$ions on $\mathrm{Pt}$ electrode in the potential range of $300 \mathrm{mV}$ with $0.5 \mathrm{M} \mathrm{H}_{2} \mathrm{SO}_{4}$ supporting electrolyte.

The reduction of nitrate $\left(\mathrm{NO}_{3}^{-}\right)$ions has received considerable attention over the last four decades, this is because of the production of valuable and useful chemicals such as Nitrous oxide $\left(\mathrm{N}_{2} \mathrm{O}\right)$, a compound used as an anesthetic in medical application, ammonia $\left(\mathrm{NH}_{3}\right)$, a nitrogen source in fertilizers, hydroxylamine $\left(\mathrm{NH}_{2} \mathrm{OH}\right)$, a material very important in the manufacture of caprolactam.

\section{Conclusion}

Nano-alumina $\left(\mathrm{Al}_{2} \mathrm{O}_{3}\right)$ adsorbent with the grain size of $50 \mathrm{~nm}$ has nitrate removal capacity. The minimum contact time required for the maximum removal efficiency is observed at 30 minutes. The dose of alumina influence the removal efficiency and the removal capacity varies with the initial concentration. In the acidic $\mathrm{pH}$ range, the removal efficiency is more. Nitrate removal efficiency decreases with temperature. The electrochemical method of nitrate removal using $\mathrm{Pt}$ anode and the brass cathode is observed to give encouraging results. The removal efficiency increases with electrolysis time. The removal efficiency is greater at the current density of 1 to $2 \mathrm{~A}$ $\mathrm{dm}^{-2}$. The direct reduction of nitrate is possible at all nitrate concentrations and starts at a potential below $300 \mathrm{mV}$ vs SCE. During the electrocatalytic reduction process, the adsorbed $\mathrm{NO}_{3}{ }^{-}$ions on the Pt electrode were reduced into $\mathrm{NO}_{2}{ }^{-}$(nitrite) ions and the $\mathrm{NO}_{2}{ }^{-}$ions are reduced into $\mathrm{NO}, \mathrm{N}_{2} \mathrm{O}$ and $\mathrm{N}_{2}$ gas.

\section{Supporting information}

Not Applicable.

\section{Conflict of interest}

There are no conflicts to declare.

\section{References}

[1] E.V.S. Prakasa Rao, K. Puttanna, Curr. Sci., 2000, 79, 11631168 . 
[2] F. T. Wakida, D.N. Lerner, Water Res., 2005, 39, 3-16, doi: 10.1016/j.watres.2004.07.026.

[3] A. Esmaeili, F. Moore, B. Keshavarzi, Environ. Earth Sci., 2014, 72, 2511-2522, doi: 10.1007/s12665-014-3159-z.

[4] L. Fewtrell, Environ. Health Persp., 2004, 112, 1371-1374 doi: 10.1289/ehp.7216.

[5] WHO, Guidelines for drinking-water quality 4th edition, World Health Organization, 2011.

[6] EPA, Drinking Water Standards and Health Advisories Tables, United States Environmental Protection Agency, 2012.

[7] M. Mazarji, B. Aminzadeh, M. Baghdadi, A. Bhatnagar, J. Mol. Liq., 2017, 233, 139-148 doi: 10.1016/j.molliq.2017.03.004.

[8] M. Dore, P. Simon, A. Deguin, J. Victot, Water Res., 1986, 20, 221-232.

[9] J.J. Schoeman, A. Steyn, Desalination., 2003, 155, 15-26 doi: 10.1016/S0011-9164(03)00235-2.

[10] A. Kapoor, T. Viraraghavan, J. Environ. Eng., 1997, 123, 371-380, doi: 10.1061/(ASCE)0733-9372(1997)123:4(371).

[11] N. Ozturk, T.E. Bektas, J. Hazard. Mater., 2004, 112, $155-$ 162, doi: 10.1016/j.jhazmat.2004.05.001.

[12] P. Loganathan, S. Vigneswaran, J. Kandasamy, J. Environ. Manage., 2013, 131, 363-374 doi: 10.1016/j.jenvman.2013.09.034.

[13] M. El Ouardi, S. Qourzal, S. Alahiane, A. Assabbane, J. Douch, Journal of Encapsulation and Adsorption Sciences, 2015, 5, 178-190. doi: 10.4236/jeas.2015.54015.

[14] F. Hell, J. Lahnsteiner, H. Frischherz, G. Baumgartner, Desalination, 1998, 117, 173-180. doi: 10.1016/S00119164(98)00088-5.

[15] A. Pintar, J. Batista, J. Levec, Catal. Today., 2001, 66, 503510, doi: 10.1016/S0920-5861(00)00622-2.

[16] M.I.M. Soares, Water Air Soil Pollut., 2000, 123, 183-193 doi: 10.1023/A:1005242600186.

[17] K.M. Hiscock, J.W. Lloyd, D.N. Lerner, Water. Res., 1991, 25, 1099-1111, doi: 10.1016/0043-1354(91)90203-3.

[18] E. Hoseinzadeh, A. Rezaee, M. Farzadkia, J. Mol. Liq., 2017, 246, 93-102, doi: 10.1016/j.molliq.2017.09.048.

[19] L.W. Canter, CRC Lewis Publishers, London, 1997.

[20] K.S. Haugen, M.J. Semmens, P.J. Novak, Water Res., 2002, 36, 3497-3506, doi: 10.1016/S0043-1354(02)00043-X.

[21] C. Della Rocca, V. Belgiorno, S. Meriç, Desalination, 2007, 204, 46-62 doi: 10.1016/j.desal.2006.04.023.

[22] N.B. Singh, G. Nagpal, S. Agrawal, Environ. Technol. Inno., 2018, 11, 187-240, doi: 10.1016/j.eti.2018.05.006.

[23] K. Ravindhranath, M. Ramamoorty, Rasayan J. Chem., 2017, 10, 716-722, doi: 10.7324/RJC.2017.1031762.

[24] M. Mazarji, B. Aminzadeh, M. Baghdadi, A. Bhatnagar, $J$ Mol. Liq., 2017, 233, 139-148, doi: 10.1016/j.molliq.2017.03.004.

[25] A. Bhatnagar, M. Sillanpaa, Chem. Eng. J., 2011, 168, 493504, doi: 10.1016/j.cej.2011.01.103.

[26] M. A. Salam, O. Fageeh, S.A. Al-Thabaiti, A.Y. Obaid, J Mol. Liq., 2015, 212, 708-715, doi: 10.1016/j.molliq.2015.09.029.

[27] S. Jain, A. Bansiwal, R.B. Biniwale, S. Milmille, S. Das, S.

Tiwari, P.S. Antony, J. Environ. Chem. Eng., 2015, 3, 2342-2349, doi: 10.1016/j.jece.2015.08.009.

[28] M.J. Garcia-Fernández, S. Sancho-Querol, M.M. PastorBlas, A. Sepulveda-Escribano, J. Colloid Interf. Sci., 2017, 494, 98-106, doi: 10.1016/j.jcis.2017.01.081.

[29] H. Demiral, G. Gunduzoglu, Bioresour. Technol., 2010, 101, 1675-1680, doi: 10.1016/j.biortech.2009.09.087.

[30] Q. Hu, H. Liu, Z. Zhang, Y. Xie, J Mol. Liq., 2020, 309, 113057 doi: 10.1016/j.molliq.2020.113057.

[31] K. Tada, T. Kawaguchi, K. Shimazu, J. Electroanal. Chem., 2004, 572, 93-99, doi: 10.1016/j.jelechem.2004.06.004.

[32] G.E. Dima, A.C.A. De Vooys, M.T.M. Koper, J. Electroanal. Chem., 2003, 554, 15-23, doi: 10.1016/S0022-0728(02)01443-2.

[33] X. Guo, C. Feng, M. Li and L. Hou, IEEE, 3rd International Conference on Bioinformatics and Biomedical Engineering, 2009, pp. 1-4, doi: 10.1109/ICBBE.2009.5162763.

[34] P.K. Prasad, M.N. Priya, K. Palanivelu, Indian J. Chem. Techn., 2005, 12, 164-169.

[35] A.K.M. Ashadullah, N. Kishimoto, International Journal of Environmental Science and Development, 2016, 7, 499-516, doi: 10.18178/ijesd.2016.7.7.828.

[36] E.T. Tech, J. environ. treat. tech., 2014, 2, 18-21.

[37] J.W. Peel, K.J. Reddy, B.P. Sullivan, J.M. Bowen, Water Res., 2003, 37, 2512-2519, doi: 10.1016/S0043-1354(03)00008-3.

[38] E. Lacasa, P. Canizares, C. Saez, F.J. Fernandez, M.A. Rodrigo, Chem. Eng. J., 2011, 171, 1012-1017, doi: 10.1016/j.cej.2011.04.053.

[39] K. Govindan, M. Noel, R. Mohan, J. Water Process. Eng., 2015, 6, 58-63, doi: 10.1016/j.jwpe.2015.02.008.

[40] G.E. Dima, A.C.A. De Vooys, M.T.M. Koper, J. Electroanal. Chem., 2003, 554, 15-23. 10.1016/S00220728(02)01443-2.

[41] M.T.De Groot, M.T.M. Koper, J Electroanal. Chem., 2004, 562, 81-94, doi: 10.1016/j.jelechem.2003.08.011.

\section{Author information}

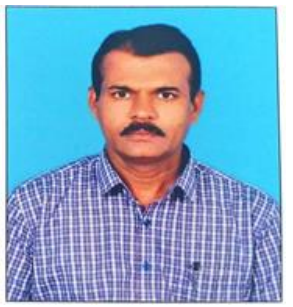

S. Ramalingam acquired his post graduate and doctoral degrees from Alagappa University (2009), India. He has served as an Assistant Professor at Kalasalingam Academy of Research and Education (Deemed to be University), 
India. He has 15 years of experience in teaching and research, as well as 8 years of industrial experience. His research interests include electrodeposition and corrosion, nanomaterials chemistry, and water analysis, and he has published many articles in renowned international and national journals.

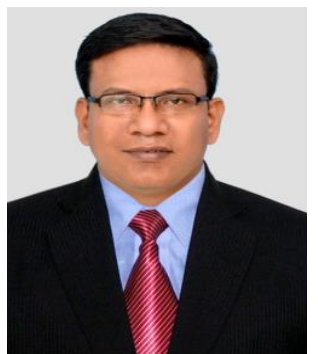

Subramania Angaiah currently working as a Professor at the Centre for Nanoscience and Technology, Pondicherry University, India. He received his Ph.D degree from CSIR-CECRI \& Alagappa University (2001) and his postdoctoral training at Korean Institute of Science and Technology (KIST), Seoul, S.Korea. His current research interests include the development of Nanostructured materials for M-ion batteries, supercapacitors, quantum dot sensitized solar cells, dyesensitized solar cells, Corrosion and Surface Engineering.

Publisher's Note: Engineered Science Publisher remains neutral with regard to jurisdictional claims in published maps and institutional affiliations. 